\title{
ECOLOGICAL CORRELATES OF POLYPHENISM AND GREGARIOUS ROOSTING IN THE GRASS YELLOW BUTTERFLY Eurema elathea (PIERIDAE)
}

\author{
RUSZCZYK, A., ${ }^{1}$ MOTTA, P. C., ${ }^{2}$ BARROS, R. L. ${ }^{3}$ and ARAÚJO, A. M. ${ }^{4}$ \\ ${ }^{1}$ C.P. 9011, CEP 90040-970, Porto Alegre, RS, Brazil \\ ${ }^{2}$ Departamento de Zoologia, Universidade de Brasília, CEP 70910-900, Brasília, DF, Brazil \\ ${ }^{3}$ Instituto de Biologia, Universidade Federal de Uberlândia, CEP 38400-902, Uberlândia, MG, Brazil \\ ${ }^{4}$ Departamento de Genética, Universidade Federal do Rio Grande do Sul, C.P. 15053, \\ CEP 91501-970, Porto Alegre, RS, Brazil \\ Correspondence to: Alexandre Ruszczyk, C.P. 9011, CEP 90040-970, Porto Alegre, RS, Brazil, \\ e-mail: rusver@terra.com.br \\ Received April 22, 2002 - Accepted April 30, 2003 - Distributed February 29, 2004
}

(With 5 figures)

\begin{abstract}
Eurema elathea adults were censused weekly (1992-1994) in six night-roosts around a forest fragment on a farm, and in two roosts in the urban area of Uberlândia, Minas Gerais, Brazil. Males were grouped in six phenotypic classes. These were based on a range between having a conspicuous wide black bar at the dorsal forewing inner margin (wet season dark morphs) and the absence of that bar (dry season light morphs). The body mass and wing area of co-occurring morphs were compared: differents morphs showed similar means. The abundance of butterflies and morph frequencies varied in close relation to humidity (rainfall). Individuals were infrequent and monomorphically dark in the wet season while light morphs predominated in dry periods when population peaked. A lower fraction of recaptured individuals and higher recruitment were recorded compared to other night-roosting butterflies. Dispersal potential was similar between the sexes and varied seasonally with a more sedentary population in dry periods. The maximum residence time recorded was 91 days for a female and 84 days for a male. The fraction of individuals that moved from one roosting site to another was similar in both sexes and male morphs, but significantly higher on the farm than in the urban area. Also, a significantly higher fraction (21.3\%) of marked butterflies was recaptured in the urban area than on the farm (15.6\%), suggesting a behavioral modification for sedentariness in the urban individuals. The selective forces shaping a gregarious roosting habit in E. elathea and other butterflies are discussed and a protocooperational strategy for saving energy is proposed.
\end{abstract}

Key words: mark-recapture, polyphenism, roosting behaviour, butterfly ecology, urban environment.

\section{RESUMO}

\section{Correlatos ecológicos do polifenismo e dormitórios gregários da borboleta-amarela-da-grama Eurema elathea (Pieridae)}

Adultos de Eurema elathea foram estudados semanalmente (1992-1994) em seis locais (dormitórios), ao redor de um fragmento de mata em uma fazenda e em dois locais na área urbana de Uberlândia, MG. Os machos foram classificados em seis categorias fenotípicas, as quais variam desde a presença de uma grande e conspícua barra preta na margem interna dorsal da asa anterior (forma escura da estação úmida) até a ausência da barra (forma clara da estação seca). A massa corporal e a área da asa foram comparadas: formas diferentes mostraram médias similares. A abundância das borboletas e a freqüência das formas variaram conforme a umidade (chuvas). Na estação úmida, os indivíduos foram menos freqüentes e monomorficamente escuros, enquanto na seca, a população aumenta e as formas 
claras predominam. As taxas de recaptura e recrutamento são comparadas com outras borboletas que se agregam durante a noite. O potencial de dispersão foi similar entre os sexos e variou sazonalmente, sendo que a população é mais sedentária no período seco. O máximo tempo de residência registrado foi de 91 dias para uma fêmea e de 84 dias para um macho. A fração de indivíduos que se moveram de um sítio de descanso para outro foi similar em ambos os sexos e formas de machos, mas foi significativamente maior na fazenda em relação à área urbana. Da mesma forma, foi recapturada uma fração significativamente maior $(21,3 \%)$ de borboletas marcadas na área urbana do que na fazenda $(15,6 \%)$, sugerindo modificação comportamental para o sedentarismo nos indivíduos urbanos. São discutidas as forças seletivas que moldam o hábito de descanso gregário em E. elathea e em outras borboletas, e propõe-se uma estratégia protocooperativa de economia de energia.

Palavras-chave: marcação-recaptura, polifenismo, agregação, ecologia de borboletas, ambiente urbano.

\section{INTRODUCTION}

Shapiro (1976) defined seasonal polyphenism as "an annually repeating pattern of changing phenotypic ratios in successive generations, under some kind of environmental control". He later reviewed the subject and discussed its relation to theories of speciation (Shapiro, 1984a). West-Eberhard, in her excellent 1989 review, treats polyphenism as an example of phenotypic plasticity which she defines as "the ability of a single genotype to produce more than one alternative form of morphology, physiological state, and/or behavior in response to environmental conditions". Although polyphenism has been viewed as an adaptive phenomenon for more than 100 years (Weismann, 1882), experimental evidence on the selective advantage of different morphs is scanty (Shapiro, 1984a) and has only been gathered recently. The morphs which were more pigmented by melanin produced in cold months in temperate regions may absorb more radiant energy, attaining temperatures necessary to fly under those conditions that would be limiting for lighter colored morphs which could reflect radiation, thus avoiding overheating (Watt, 1968; Douglas \& Grula, 1978; Kingsolver \& Watt, 1983; Kingsolver, 1987; Kingsolver \& Wiernasz, 1991). Kingsolver (1995a, b, 1996) showed experimentally the superior fitness of seasonal phenotypes of Pontia occidentalis in environments where they were frequent compared to alternative ones. Summer light morphs tend to be less active and may theoretically decrease predation pressure via crypsis optimization in a dry background (Brakefield \& Larsen, 1984).
Photoperiod and/or temperature (Ae, 1957; McLeod, 1968, 1984; Douglas \& Grula, 1978; Jones et al., 1985; Nylin, 1989; Smith, 1991; Windig \& Lammar, 1999) were pointed out as the primary cue controlling phenotypic change for both temperate and tropical butterflies.

The polyphenic Eurema elathea adults are gregarious night-roosters in natural and disturbed fields, disturbed woods, and both agricultural, and suburban habitats of Central Brazil (Brown, 1992; Rodrigues et al., 1993). Exotic plants cultivated for human food (peanut, Arachis hypogaea, and soybean, Glycine max), ornamentals (Calliandra tweedii, Delonyx regia, and Senna spp.), Thevetia sp., Zornia sp., and Stylosanthes sp. are used as larval host plants (Biezanko, 1958; DeVries, 1987; Brown, 1992).

In this paper we investigate morphometrical, phenological, and behavioral differences within male seasonal phenotypes of Eurema elathea. We also discuss the ecological and evolutionary significance of polyphenism and gregarious roosting habit in butterflies using E. elathea as an example.

\section{MATERIAL AND METHODS}

\section{Study area}

Samples were taken in six night-roosts located in a field bordering a 7.5 ha forest fragment on Marileusa Farm, on the outskirts of the city of Uberlândia $\left(18^{\circ} 55^{\prime} \mathrm{S}, 48^{\circ} 17^{\prime} \mathrm{W}\right.$, State of Minas Gerais), Brazil, and two roosts on the campus of the Federal University of Uberlândia (a residential area $1.7 \mathrm{~km}$ from Marileusa Farm). Hereafter, the two groups of roosts will be referred to as the 
"farm" and "urban" roosts. Roosts were patches of Brachiaria spp. grass with scattered small shrubs (mainly Sida rhombifolia) shaded by large branches projected from trees at the forest edge. Moderate cattle grazing on the grasses of the roosts was observed in the farm at noon. Due to these factors, the attenuation of solar radiation, rainfall, heat loss at night, and a shorter and less dense herb layer were observed in the roosts rather than in nearby fields. In the campus roosts there were two patches of grass in the shade of Melia azedarach trees. These urban roosts were located at opposite ends ( $85 \mathrm{~m}$ apart) of a rectangular $(98 \times 80 \mathrm{~m})$ fenced square used for the experimental cultivation of vegetables and cereals. The square was surrounded by paved streets and sidewalks, and roosts were located near the fence (easy to cross for the butterflies), a few meters off the sidewalk. One roost faced an off-campus one-storey residential square and the other faced a two-storey university building.

Rainfall is markedly seasonal in the region with a wet period in the summer (November-March) and a dry period in the winter (April-August). The temperature is not much variable in the region (Fig.
2C). Mean monthly maximal and minimal temperatures during the research ranged from 26.8 to $31.7^{\circ} \mathrm{C}$ and 13.5 to $19.7^{\circ} \mathrm{C}$, respectively.

\section{Classification and measurement of phenotypes}

Male phenotypes were grouped in six classes according to the black bar at the dorsal forewing inner margin (Fig. 1), the most conspicuous character varying in the male dorsal forewing. The black bar can be wide and rectilinear (class I morph), or be absent (class VI). Class II morphs present a narrower and more curved bar than class I. The bar of class III morphs is sinuous and narrower than class II, and its middle portion can be lacking. Class IV morphs present only the distal portion of the bar (nearly $1.5 \mathrm{~mm}$ long). Class $\mathrm{V}$ morphs present trace or spot vestiges of the distal portion of the bar (1 $\mathrm{mm}$ or less).

From May to June 1996, 35 co-occurring males of each morph class and 39 females grouped as "light" and "dark" morphs were collected near the roosts on the farm and kept in paper envelopes. They were weighed in the laboratory and their wing areas were measured (transparent millimeter-ruled paper).
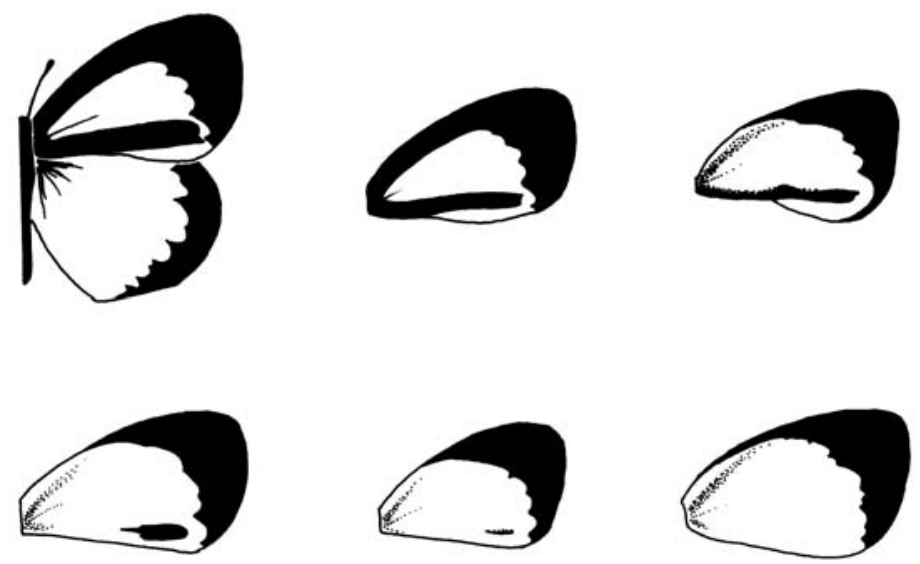

Fig. 1 - Dorsal view of male forewing phenotypes. Class I (top, left) to class VI (bottom, right) morphs. 


\section{Field sampling and analysis}

From May 1992 to June 1994 the roosts on the farm were censused weekly, early in the morning (7:00-8:30 h) when inactivity facilitates the capture of almost all the roosting butterflies. From August to November 1992 a census was performed at the urban roosts for comparative purposes. Two of us (AR and PCM) spent 15 to $20 \mathrm{~min}$ at each roost netting the perched or slow-flying disturbed individuals. They were numbered in the ventral hindwings, sexed, and the morph class, wing wear (three classes: worn, intermediate, and fresh), presence of beak-marks on the wings, and recaptured individuals were noted. Marked butterflies were put into a cylindrical $(75 \varnothing \times 90$ $\mathrm{cm})$ muslin cage and released before the next roost was sampled. We caged the butterflies due to high multiple recapture of already released butterflies in a pilot study. From May to June 1992 the roosts on the farm went through daily censuses during two alternate weeks to track individual movements of butterflies between roosts.

Analysis of variance was used to compare the means of body mass and wing area of different morphs and their mean residence time (days elapsed between marking and last recapture). For the latter analysis, the data were normalized by log-transformation and classes I-II, III-IV, and V-VI were pooled to increase sample size.

\section{RESULTS}

Females were heavier $(t=2.621, d f=247$, $\mathrm{p}=0.01)$ than males and their total wing area was larger $(t=3.487, d f=247, \mathrm{p}=0.01)$ (Table 1$)$; the same was true for both the hindwing and forewing area. Co-occurring male morphs showed statistically similar means for body mass $\left(F_{(5,204)}=1.880, \mathrm{p}=\right.$ $0.899)$, forewing area $\left(F_{(5,204)}=0.566, \mathrm{p}=0.726\right)$, hindwing area $\left(F_{(5,204)}=0.616, \mathrm{p}=0.688\right)$, and total wing area $\left(F_{(5,204)}=0.535, \mathrm{p}=0.750\right)($ Table 1$)$. The same occurred for light $v s$. dark female morphs.

The abundance of butterflies closely matched rainfall variation (Fig. 2AB). The population peaked in dry periods and decreased in super-humid months (rainfall above $100 \mathrm{~mm}$, Fig. 2C). The frequency of male morphs varied seasonally concurrently with rainfall (Fig. 2D). The darkest morphs (classes I and II) were observed in super-humid periods but were only a small fraction of the males in dry periods when clear morphs predominated (classes $\mathrm{V}$ and VI). Intermediate morphs (classes III and IV) represented a stable proportion of nearly $20 \%$ of the males in dry and humid periods (Fig. 2D).

Of the 2,217 adults marked on the farm $(1,549$ males, 668 females, sex ratio $=2.32), 236$ were recaptured ( 157 males, 79 females, sex ratio $=1.99$ ), with statistically similar fractions of the sexes marked and recaptured $\left(\chi^{2}=1.126, d f=1, \mathrm{p}=0.289\right)$.

TABLE 1

Morphometric means ( \pm SD) of Eurema elathea phenotypes. Bold figures indicate significant difference $(p<0.05$, t-test) between phenotypes. Data from butterflies collected in May-June 1996 in Uberlândia, Brazil.

\begin{tabular}{|c|c|c|c|c|c|}
\hline Phenotypes & $\begin{array}{c}\text { Number } \\
\text { measured }\end{array}$ & $\begin{array}{c}\text { Body mass } \\
\mathbf{( m g )}\end{array}$ & $\begin{array}{c}\text { Forewing } \\
\left.\text { area } \mathbf{( m m}^{\mathbf{2}}\right)\end{array}$ & $\begin{array}{c}\text { Hindwing } \\
\text { area } \mathbf{( m m}^{\mathbf{2}} \mathbf{)}\end{array}$ & $\begin{array}{c}\text { Total wing } \\
\text { area }\left(\mathbf{m m}^{\mathbf{2}}\right)\end{array}$ \\
\hline Males I & 35 & $26.5 \pm 3.32$ & $136.7 \pm 11.45$ & $161.1 \pm 14.56$ & $297.9 \pm 25.01$ \\
\hline II & 35 & $24.0 \pm 4.43$ & $132.3 \pm 14.50$ & $155.3 \pm 17.84$ & $287.6 \pm 31.47$ \\
\hline III & 35 & $25.0 \pm 4.45$ & $133.3 \pm 12.50$ & $159.4 \pm 16.20$ & $292.7 \pm 27.78$ \\
\hline IV & 35 & $25.7 \pm 4.20$ & $135.4 \pm 10.01$ & $157.1 \pm 15.19$ & $292.5 \pm 24.52$ \\
\hline V & 35 & $26.2 \pm 3.28$ & $135.5 \pm 12.20$ & $159.3 \pm 14.22$ & $294.7 \pm 25.34$ \\
\hline VI & 35 & $25.2 \pm 3.80$ & $134.7 \pm 14.72$ & $157.0 \pm 16.10$ & $291.7 \pm 29.58$ \\
\hline Dark females & 19 & $27.4 \pm 3.96$ & $146.0 \pm 8.32$ & $167.0 \pm 11.45$ & $312.9 \pm 18.78$ \\
\hline Light females & 20 & $27.3 \pm 7.03$ & $142.7 \pm 13.62$ & $163.0 \pm 15.82$ & $305.7 \pm 28.00$ \\
\hline All females & 39 & $\mathbf{2 7 . 4} \pm \mathbf{5 . 6 7}$ & $\mathbf{1 4 4 . 3} \pm \mathbf{1 1 . 3 3}$ & $\mathbf{1 6 4 . 9} \pm \mathbf{1 3 . 8 4}$ & $\mathbf{3 0 9 . 2} \pm \mathbf{2 3 . 9 3}$ \\
\hline All males & 210 & $\mathbf{2 5 . 4} \pm \mathbf{3 . 9 9}$ & $\mathbf{1 3 4 . 7} \pm \mathbf{1 2 . 6 0}$ & $\mathbf{1 5 8 . 2} \pm \mathbf{1 5 . 6 6}$ & $\mathbf{2 9 2 . 9} \pm \mathbf{2 7 . 2 5}$ \\
\hline
\end{tabular}



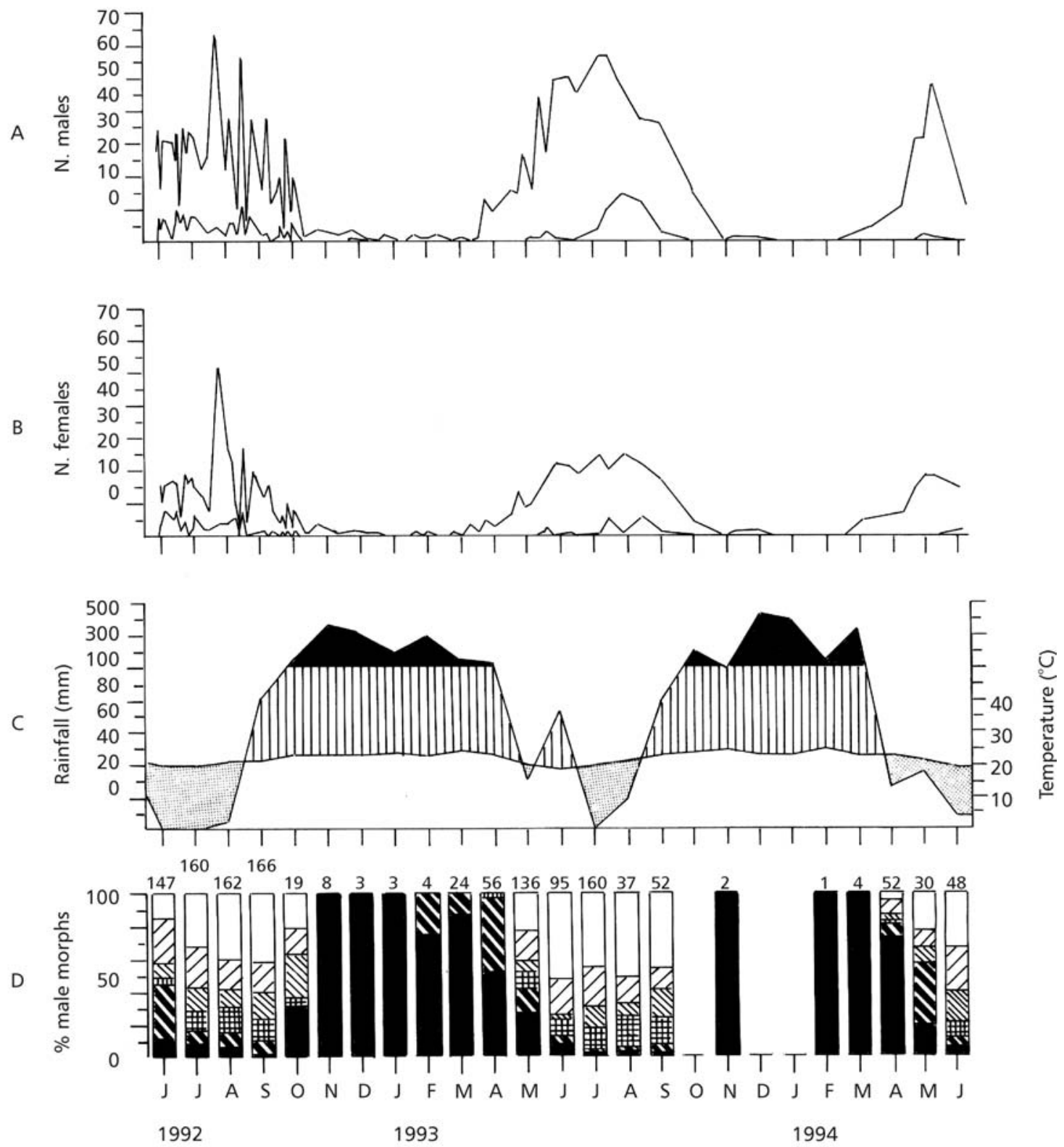

Fig. 2 - Number of Eurema elathea males (A) and females (B) marked and recaptured (lower curves). C, climatogram during the sampling period, after Walter (1971): jagged line, monthly rainfall (mm); smooth lower line, mean monthly temperature, dry (dotted), humid (hatched), and super-humid (black) periods. D, monthly percentage of male phenotypes. Phenotypes I, II, III, IV, V, VI legends can be seen from the bottom to the upper part of each bar, respectively. Numbers above the bars are sample sizes. 
On the two urban roosts, 188 adults were marked (112 males, 76 females, sex ratio $=1.47)$, of which 40 were recaptured ( 22 males, 18 females, sex ratio $=1.22)$, also with a statistically similar fraction of the sexes marked and recaptured $\left(\chi^{2}=\right.$ $0.285, d f=1, \mathrm{p}=0.595)$. In both areas, there were no significant differences between the sexes regarding the probability of being recaptured $\left(\chi^{2}=0.07, d f=\right.$ $1, \mathrm{p}=0.792$ on the farm; $\chi^{2}=0.441, d f=1, \mathrm{p}=$ 0.506 in the urban area).

A significantly higher proportion $(21.3 \%)$ of individuals marked (males plus females) were recaptured in the urban area than on the farm $\left(15.6 \%, \chi^{2}=4.028, d f=1, p=0.045\right)$. If the data obtained on the farm is limited to the period from August to November 1992 (when the urban area was sampled) the difference is even greater $(8.2 \%$ recaptured in the farm of a total of 390 individuals marked, $\left.\chi^{2}=19.875, d f=1, \mathrm{p}<0.001\right)$.

The maximum residence time was recorded for a female marked in roost $\mathrm{A}$ and recaptured after 91 days in roost F. Two other females were recaptured 83 and 80 days after being marked on the farm and two males with 84 and 76 days. The mean residence time for pooled males (mean \pm SE, 19.29 \pm $1.30, n=134)$ and females $(20.12 \pm 2.07, n=69)$ was similar. Dark morphs (class I plus II, $16.94 \pm$ $3.67, n=18$ ), intermediates (class III plus IV, $20.99 \pm$ 2.34, $n=31$ ), and light morphs (class V plus VI, $17.36 \pm 2.68, n=72)$ showed statistically similar residence times $\left(F_{(2,118)}=1.837, \mathrm{p}=0.164\right)$.

Wing-wear classes showed a predominance of fresh wings (characteristic of recently emerged or "new" individuals) throughout the whole sampling period, specially in the males (Fig. 3).

Worn or intermediate classes accounted for less than $15 \%$ of the males recorded; female wing- wear classes presented a higher variation than did those of males. Only $1.6 \%$ of the individuals bore beak marks on the wings.

Males of the darkest morph (class I) were recaptured significantly less than males from other classes $\left(\chi^{2}=25.653, d f=5, \mathrm{p}<0.05\right.$, Table 2$)$; they did not differ, however, from class II morphs $\left(\chi^{2}=\right.$ $2.020, d f=1, \mathrm{p}=0.155)$. Individuals were more sedentary in the dry season compared to the wet season. All the 30 males and 12 females with residence time higher than 30 days were recaptured in the dry season (July-September both 1992 and 1993) with a single exception (one male recaptured during the super-humid period of November 1992).

The relative abundance of different morphs in different roosts was statistically similar (Table 3). Multi-recaptured butterflies showed a "move to a roost - stay for some days - move again" pattern of dispersal between roosts (Fig. 4). Dispersal between roosts may reach relatively large distances: two males marked in the urban area were recaptured on the $1.7 \mathrm{~km}$ distant farm!

The number of individuals changing roosts depended more on the distance between the roosts than the number of individuals marked (Table 3 , Figs. 4A, 5). A significantly higher fraction of migrant butterflies were permuted with roost $C$, located at the shortest mean distance from the other roosts $\left(\chi^{2}=21.453, d f=5, \mathrm{p}<0.01\right)$. Few butterflies were permuted with the relatively isolated roost $\mathrm{F}$ (Table 3, Fig. 5), althought differences among roosts $\mathrm{A}, \mathrm{B}, \mathrm{D}, \mathrm{E}$, and $\mathrm{F}$ were not statistically significant $\left(\chi^{2}=4.521, d f=4, \mathrm{p}>0.05\right)$. On the farm, the proportion of individuals remaining in a given roost or moving to another was similar between the sexes $\left(\chi^{2}=0.502, d f=1, \mathrm{p}=0.479\right)$ and among male morphs $\left(\chi^{2}=1.623, d f=5, \mathrm{p}=0.899\right.$, Table 4).

TABLE 2

Male morphs of Eurema elathea marked and recaptured. Pooled data recorded in May 1992-June 1994 in six night-roosts in Uberlândia, Brazil. Different superscript letters indicate significant differences $\left(p<0.05, \chi^{2}\right.$ test) between morph classes in the fraction of marked individuals recaptured.

\begin{tabular}{|l|c|c|c|c|c|c|}
\hline \multicolumn{7}{|c|}{ Male morph classes } \\
\hline & I & II & III & IV & V & VI \\
\hline N. marked & 226 & 174 & 140 & 148 & 263 & 431 \\
\hline N. recaptured & 12 & 11 & 14 & 22 & 29 & 50 \\
\hline$\%$ recaptured & $5.3^{\mathrm{a}}$ & $6.3^{\mathrm{a}}$ & $10.0^{\mathrm{b}}$ & $14.9^{\mathrm{b}}$ & $11.0^{\mathrm{b}}$ & $11.6^{\mathrm{b}}$ \\
\hline
\end{tabular}


TABLE 3

Percent of Eurema elathea phenotypes in six roosts (A-F) in Uberlândia, Brazil (sum of data recorded in May 1992June 1994). G, Pooled data recorded in August-November 1992 in two roosts in the campus of the Federal University of Uberlândia. Number of dispersing butterflies (marked in other roost) recorded in each roost is shown in parentheses. Different superscript letters indicate significant differences $\left(p<0.01, \chi^{2}\right.$ test) between roosts $(A-F)$ in sex ratio and fraction of dispersing individuals.

\begin{tabular}{|c|c|c|c|c|c|c|c|}
\hline \multirow{2}{*}{$\begin{array}{c}\text { Phenotypes } \\
\text { Male morph classes }\end{array}$} & \multicolumn{7}{|c|}{ Roosts } \\
\hline & $\mathbf{A}$ & B & $\mathbf{C}$ & D & $\mathbf{E}$ & $\mathbf{F}$ & $\mathbf{G}$ \\
\hline I & 16.5 & 21.5 & 12.2 & 13.8 & 15.8 & 18.0 & 11.8 \\
\hline II & 14.9 & 14.1 & 11.6 & 12.6 & 11.4 & 10.0 & 9.2 \\
\hline III & 9.8 & 9.8 & 9.6 & 16.1 & 11.9 & 8.4 & 13.6 \\
\hline IV & 11.7 & 8.3 & 10.5 & 13.8 & 12.4 & 9.2 & 12.7 \\
\hline V & 18.2 & 22.4 & 19.0 & 11.5 & 16.9 & 21.6 & 20.9 \\
\hline VI & 28.9 & 23.9 & 37.1 & 32.2 & 31.6 & 32.8 & 31.8 \\
\hline$N$ & 369 & 205 & 294 & 87 & 177 & 250 & 110 \\
\hline Other males* & 61 & 43 & 54 & 1 & 1 & 15 & 2 \\
\hline Total males & 430 & 248 & 340 & 88 & 178 & 265 & 112 \\
\hline Total females & 202 & 93 & 112 & 44 & 89 & 128 & 76 \\
\hline Total individuals & 632 & 341 & 452 & 132 & 267 & 393 & 188 \\
\hline Sex ratio $(\mathrm{ma} / \mathrm{fe})$ & $2.13^{\mathrm{a}}$ & $2.67^{\mathrm{ab}}$ & $3.04^{\mathrm{b}}$ & $2.0^{\mathrm{a}}$ & $2.0^{\mathrm{a}}$ & $2.07^{\mathrm{a}}$ & 1.47 \\
\hline N. dispersing & $(18)^{\mathrm{a}}$ & $(23)^{\mathrm{a}}$ & $(40)^{\mathrm{b}}$ & $(23)^{\mathrm{a}}$ & $(15)^{\mathrm{a}}$ & $(13)^{\mathrm{a}}$ & (3) \\
\hline Roost area sampled $\left(\mathrm{m}^{2}\right)$ & 570 & 96 & 143 & 195 & 400 & 162 & 200 \\
\hline
\end{tabular}

* Individuals with unrecorded or dubious morph class data registered mainly in May 1992, at the beginning of the sampling program.

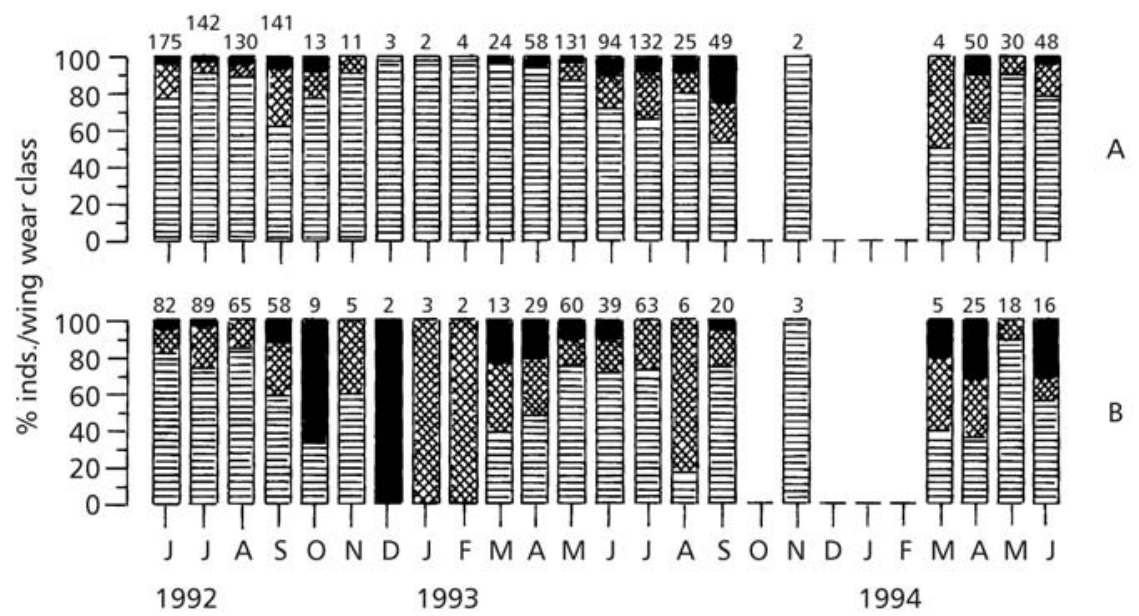

Fig. 3 - Wing wear classes of Eurema elathea males (A) and females (B). Black: worn and very worn; squared: slightly worn; striped: unworn. Numbers above the bars are sample sizes. 
TABLE 4

Number of Eurema elathea phenotypes recaptured after marking in the same roost or in another. Sum of data recorded in May 1992-June 1994 in six night-roosts around a forest fragment (7.5 ha) in Uberlândia, Brazil. Data recorded in August-November 1992 in two roosts in the campus of the Federal University of Uberlândia are shown in parentheses.

\begin{tabular}{|l|c|c|}
\hline \multicolumn{1}{|c|}{ Mhenotypes } & Same roosting site & Other roosting site \\
\hline I & $6(2)$ & 4 \\
\hline II & $8(1)$ & 7 \\
\hline III & $7(2)$ & 11 \\
\hline IV & $11(3)$ & 14 \\
\hline V & $13(5)$ & $16(1)$ \\
\hline VI & $26(8)$ & 27 \\
\hline Other males* & 18 & 13 \\
\hline Total males & $89(21)$ & $92(1)$ \\
\hline \multicolumn{2}{|c|}{$42(16)$} & $47(2)$ \\
\hline
\end{tabular}

Nearly half of the recaptured individuals remained in the same roost where they were marked (or previously recaptured). The situation was quite different in the urban roosts: of the 40 individuals recaptured there, only three moved to another roost (Table 4). Very few solitary individuals were found roosting outside the sites studied.

The scarcity of individuals roosting in areas between roosts was confirmed during censuses, when the authors walked from one roost to another bordering the forest fragment. The ranking of butterfly abundance among roosts also remained stable, with roosts A and D (Fig. 4A, Table 3) yielding the highest and the lowest number of records, respectively.

The area occupied by roosting butterflies in each roost was also constant during the research.

Butterflies began to congregate for nightroosting in mid-afternoon (between 15:30 and 16:00 h) and dispersed to nearby areas at 8:45-9:30 the following morning. Groups of 5 to 10 night-roosting individuals were observed in grassy spots of vacant lots in the residential squares near the campus.

Eurema elathea was observed feeding on the nectar of ruderal plants at the sides of the road which crosses the forest fragment (shown in Fig. 4), but individuals were restricted to within a few meters of the margins and did not invade the forest shade unless persecuted. Females were observed laying their eggs singly on the underside of Stylosanthes leaves. Males were frequent visitors of cattle dung during the sunniest hours of the day.

\section{DISCUSSION}

\section{Ecological correlates of polyphenism}

Owen (1971) noted that seasonal morphs of Precis octavia in Africa were larger in the dry season than in the wet season. Jones (1992) measured the forewing length of morphs from the dry and wet seasons in five Australian representatives of the genus Eurema, and was able to show that in four species, dry season morphs were larger, with the fifth species showing the reverse pattern. In the present study no differences in size were detected among co-occuring morphs, irrespective of which sex was considered. It appears that size is only related to sexual dimorphism, since females as a whole are larger than males.

The abundance of E. elathea adults was strongly related to monthly rainfall, with population increases in the dry season and reductions in the wet season. Similar rainfall-related changes in abundance of adult butterflies are common in Central Brazil and other tropical regions with a similar climate (Owen, 1977; Ebert, 1969; Rodrigues et al., 1993; Fortunato \& Ruszczyk, 1997). In subtropical parts of Brazil (e.g., the State of Rio Grande do Sul) however, abundance is closely related to temperature, with summer and autumn population peaks (Saalfeld \& Araújo, 1981). 

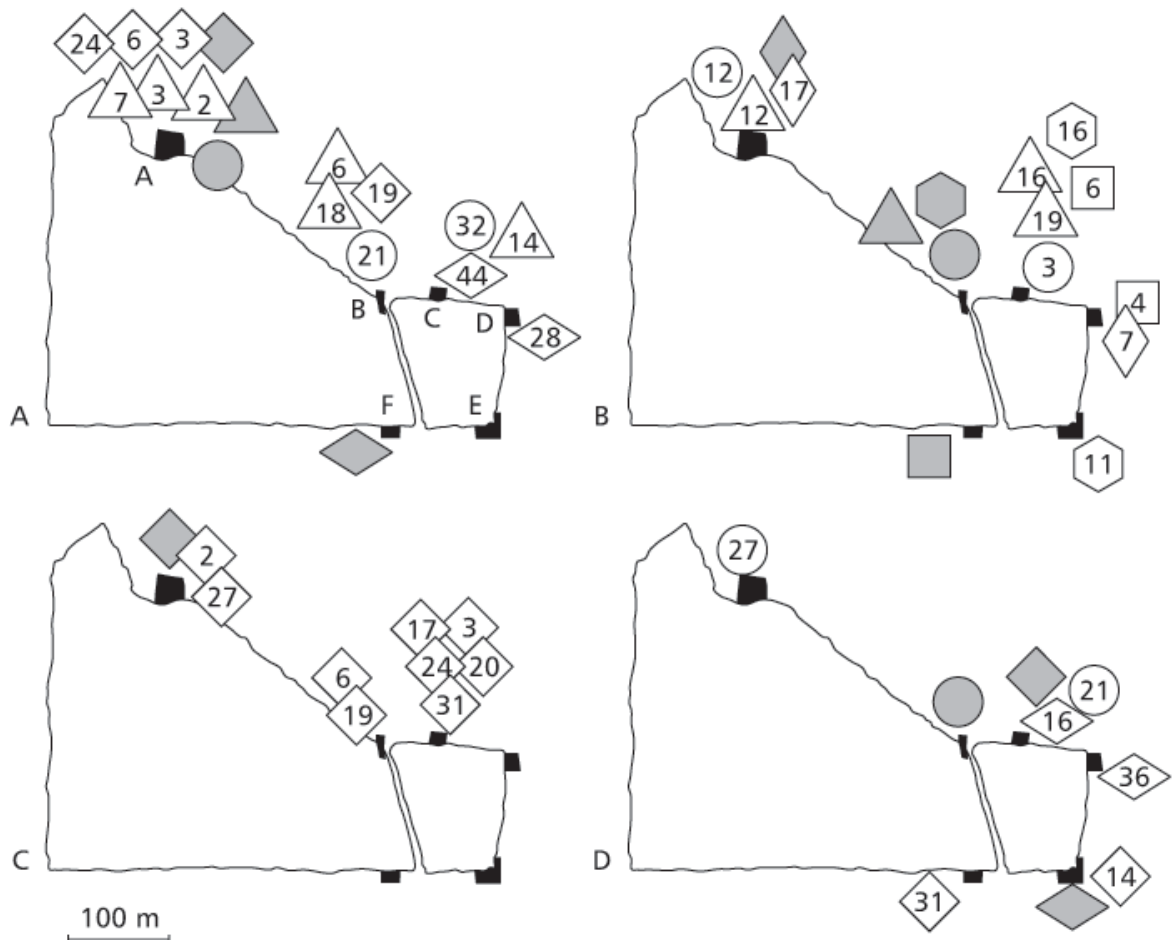

Fig. 4 - The dispersal of four females (A) and nine males (B, C and D) of Eurema elathea from roosts where they were marked (shaded symbols) to other roosts (A, B, C, D, E, F in Fig. 4A) around a forest fragment in Uberlândia. Days elapsed since marking are given within the symbols. Black areas represent roosting sites. For each figure, each kind of symbol represents the same individual. Marking and recaptures represented outside and closer the roosting areas for convenience.

The maximum residence time of nearly three months recorded for some males and females contrasts with the comparatively lower values generally recorded for other pierid species (Scott, 1973; Hayes, 1981). Our values are even higher than those obtained by Vanini et al. (2000), for the State of São Paulo (Brazil) with the same species; they recorded 52 and 54 days for the maximum residence time, respectively for males and females. Their average values were also much less than the ones reported here (it should be noted that their sampled area was more prone to disturbance than ours). Ours, however, are comparable to those recorded for the relatively long-lived tropical forest pierid Perrhybris lypera, and nymphalids like Victorina spp. (Young, 1972), Heliconius ethilla (Ehrlich \& Gilbert, 1973), H. erato (Saalfeld \& Araújo, 1981; Romanowsky et al., 1985), Hamadryas feronia, H. februa, and Callicore sellima (Fortunato \& Ruszczyk, 1997).
Eurema elathea continually moved from one roost to another, resulting in few recaptures $(15.6 \%)$ and high recruitment in the roosts. It underwent its highest dispersal potential with the dark morphs in the wet period. These dark morphs were recaptured at a lower frequency than the other morphs, contributing to the observed reduction in numbers during the wet season. Paul Opler (unpublished study cited in DeVries, 1987) demonstrated similar behavioral differences between Eurema daira morphs in Costa Rica, with sedentary individuals in the dry and migratory in the wet season. Roosting in E. elathea differs from that observed for $E$. daira and $E$. proterpia (DeVries, 1987) since, in the former, roosting sites were utilized only for the night rest, with butterflies dispersing to peripheral areas the following morning (no torpid or diapause aggregating adults were observed, as was the case for the two latter species). 


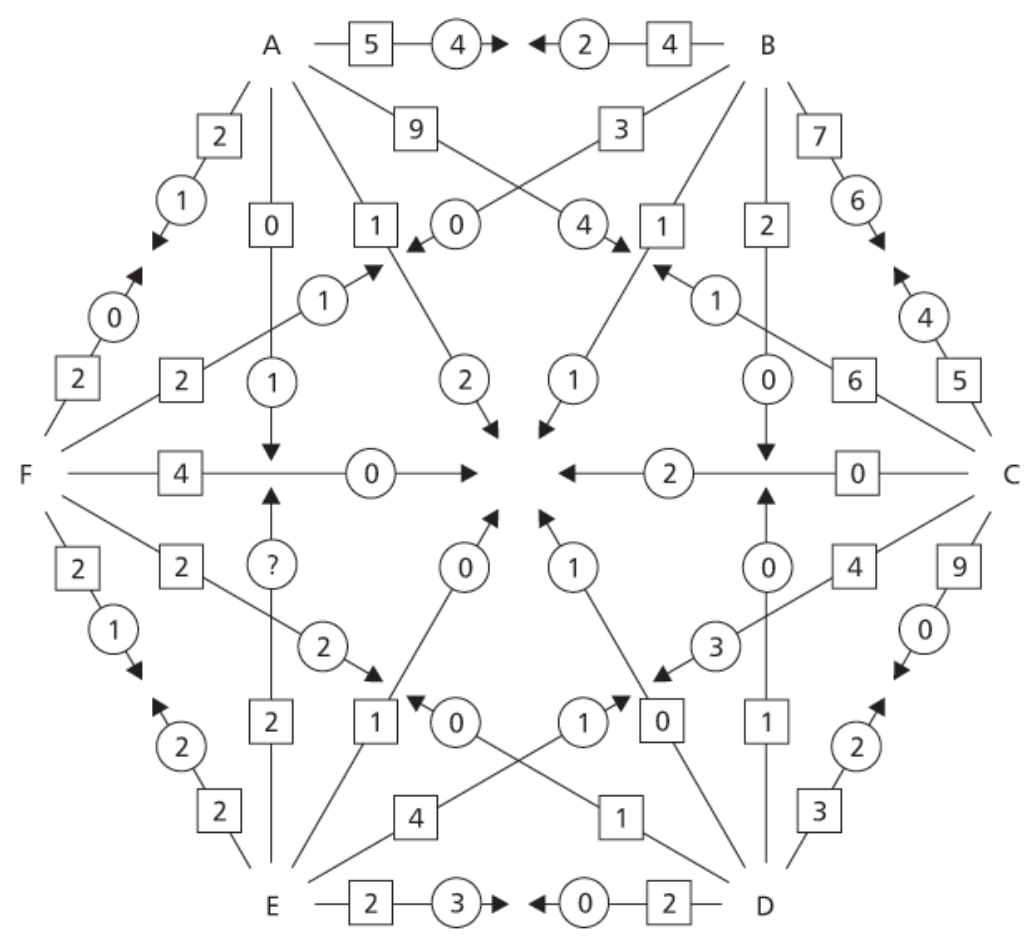

Fig. 5 - Scheme of Eurema elathea movements between six night-roosts in Marileusa Farm, Uberlândia. Sum of data collected in 1992-1994. The number of individuals permuted between roosts is indicated within circles (females) and squares (males).

In Australian savanna, species of Eurema were found to be reproductively dormant during the dry season (Jones \& Rienks, 1987) as were the Central American E. proterpia (DeVries, 1987) and E. daira.

Individuals were more sedentary in the urban area than on the farm, as revealed by a greater fraction of butterflies recaptured and a small frequency of individuals moving between roosts. This may represent a behavioral response of individuals to reduced patch size and the compartment-like nature of the urban habitat. Instead of leaving the area (like the absent stenoecious species of the region), E. elathea used its inherent behavioral plasticity to mitigate landscape differences among habitats (see Roitberg \& Mangel, 1997). This involved sedentariness or increase in residence probability, in accordance with the With et al. (1997) model of landscape connectivity and population distribution.

The capacity to utilize patches within disturbed natural habitats, urban areas as night-roosts, and exotic cultivated plants in larval feeding are good examples illustrating the wide ecological niche of
E. elathea. Agriculture and cattle breeding resulted in the transformation of forests into clearings and open fields, thus enlarging the habitat suitable for this sun-loving butterfly.

Cattle grazing maintains the habitat in early successional stages, preventing the overshadowing of butterfly food plants by competing grasses, and providing an abundant source of dung where males congregate. Time-segregated diurnal cattle grazing and night-roosting resulted in no harm or disturbance to the perched butterflies, although the tiny immature ones are at risk of being eaten or trampled.

On theoretical grounds, Brakefield \& Larsen (1984) proposed that dry season morphs (which are in general a faded color and eyespotless compared to wet season morphs) may be better protected from predation due to an optimization of crypsis in a drought background. We believe this is not the case of E. elathea since melanization (or its opposite, in the dry season) is probably related to thermal regulation, not to crypsis. 
Our data showed different male morphs living together (synchronously and in the same habitat) throughout most of the research. Males were monomorphic only during parts of the super-humid periods. As for the Australian Eurema laeta (Jones et al., 1985), greater phenotypic variability was recorded in the dry season compared to the wet season. The co-occurrence of two or more different morphs with intermediates representing a small fraction in the same population is the rule for polyphenic species, and has been observed in the study of Vanini et al. (2000) with E. elathea from southeastern Brazil as well as in Australian species of the genus Eurema (Jones et al., 1985; Jones, 1992), and in African satyrids and nymphalids (McLeod, 1968; Owen, 1971; Brakefield \& Larsen, 1984; Windig et al., 1994). Hovanitz (1941) observed for North American butterflies that geographical and seasonal variation of butterfly pigments in relation to the physical environmental factors was "too great to have much effect on cryptic coloration", and concluded that adaptiveness of color variation may be "a secondary product of some physiological change in development, metabolism or hardiness which are of primary adaptive value". This idea was previously formulated by Ford $(1937,1940)$ discussing industrial melanism and was recently pointed out by Brakefield (1996) as a problem in interpreting (based exclusively on wing pattern differences) the field tests of the adaptive hypotheses of polyphenism made by Kingsolver (1995a, b, 1996).

Traits important for survival other than coloration pattern and its associated thermoregulatory function are linked to specific phenotypes or vary among them (Shapiro, 1984a). For example, in $E$. elathea (our data), E. daira and E. proterpia (DeVries, 1987), Ascia monuste (Nielsen, 1961), and Nathalis iole (Douglas \& Grula, 1978) high melanization was correlated with a high tendency to dispersal, and sedentariness to low melanization or lighter coloration; in Precis octavia (McLeod, 1984) and Eurema boisduvaliana (DeVries, 1987), different morphs differ in microhabitat and habitat selection, respectively.

The ecological and evolutionary significance of seasonal polyphenism in butterflies may be viewed as an advantage allowing a species a seasonal diversification of its fundamental niche brought about without directional selection and disruption of co-adapted gene complexes (Shapiro, 1984a, b). In other words, polyphenism involves several components of the phenotype, without generating a genetic load. Body size and form (with their broad ecological consequences), behavioral traits, thermoregulatory function, anti-predation devices, and habitat variety which the species can successfully colonize are all diversified, enlarged, or optimized by rapid, environmentally controlled phenotypic switching. As a result of enlarged niches, polyphenic species tend to be very common and widespread, providing abundant records in field studies. The Pieridae family, in which polyphenic traits are common, may harbor the most widespread, abundant, and disturbance-tolerant species of butterflies in the world. Certainly, polyphenic traits are in part associated with the ecological success and low frequency of endemism in this family. Thus, we predict that polyphenic species will be infrequent on the regional faunal list of species at risk of extinction.

\section{Ecological correlates of gregarious roosting}

Turner (1975) summarized the expected implications of life history traits to be found in gregariously roosting butterflies: high longevity, unpalatability, slow reproductive maturation (coupled with slow production of food plants), and restricted home ranges (low vagility). With the exception of the latter, all the other characteristics may be found in greater or lesser intensity in E. elathea. On the other hand, site fidelity was less pronounced, recruitment was higher, and spacing among roosting individuals was greater than those verified in other night-roosting butterflies (Benson, 1972; Benson \& Emmel, 1973; Muyshondt \& Muyshondt, 1974).

The main selective forces shaping the gregarious roosting habit in E. elathea may be best analyzed by observing some life history traits of the species which seem to be at the extreme portions of the supposed $r$ - $K$ continuum of selective strategies (Pianka, 1994). Bird predation, which is one of the main selective forces acting on life history traits and coloration pattern of gregariously roosting butterflies studied (Benson, 1972; Calvert et al., 1979; Lederhouse et al., 1987), may not be important based on the very low frequency of beak damaged butterflies. We realize, however, that a low beak-mark frequency can be interpreted both as a high rejection and/or escape probability as well as high palatability with 
little likelihood of escape (Shapiro, 1974). Currently, we do not know which is the case for E. elathea. Thevetia sp., one of the larval food plants, synthesizes chemical deterrents to herbivores (Brown, 1992) which could reduce the palatability of the butterfly. To reinforce the idea of unpalatability, Eurema daira and $E$. proterpia were rejected by caged jacamars in Costa Rica (P. Chai cited in DeVries, 1987).

Because E. elathea is small and energetically resists handling, the bending of and pressing on their forewing costal margins over the surface of our finger tips increased the traction required to release the body and broke off wing fragments in a lever-like manner as they attempted to escape. When pursued, individuals tend to fly toward the nearest forest edge, perching a few meters inwards and remaining motionless during some minutes. The normal pattern of flight is a rapid zigzag at ground level which may discourage bird attack. These behavioral traits coupled with the low energetic reward for a nearly $30 \mathrm{mg}$ food item probably reduce bird predation events and their success. Beak marks appeared only in $1.6 \%$ of the butterflies while $30 \%$ to $50 \%$ of some nymphalids of the nearby forest fragment bore beak damage on their wings (Fortunato \& Ruszczyk, 1997).

Predators of E. elathea adults may be found among small lizards and lycosid spiders occasionally observed foraging in the roosts at mid-afternoon and early morning, respectively. Jones \& Rienks (1987) cited equivalent small predators as the main natural enemies of perched Eurema in Australia.

Some individuals were recaptured three months, after being marked (prior to which some unrecorded time had elapsed) indicating a long adult life. The energetically expensive long life of $E$. elathea adults has an important extra cost represented by its dispersal tendency, common in species from temporary or disturbed habitats (Southwood, 1962; Shreeve, 1981).

Their small size, high and variable abundance (dominant in field environments), possibility of larval consumption of the available, relatively ephemeral and generally small food plants, early successional habitat, dispersal trait, low frequency of old-age class individuals in the population, and tolerance to disturbed environments are $r$ traits of a colonizing species (Parsons, 1982). Long adult life, reproductive delay, behavioral traits related to predator escape, and night-roost habit with its inherent sensorial and behavioral complexities are $K$ traits. Gregarious roosting in $E$. elathea may have evolved as a protocooperational strategy for saving energy in a dispersing, long-lived, and high energy consuming/ per day species. Mating opportunities, number of ovipositional events (constrained in single egg laying pierids by climatic factors and disturbance from males attempting to mate Rutowski, 1978; Hayes, 1981; Courtney \& Duggan, 1983; Kingsolver, 1987), distance reached in daily dispersal, and relative protection against occasional surface predators were maximized. Incidentally, Shapiro (pers. comm.) argues that gregarious roosting is commoner in temperate zones, as opposed to that which is commonly thought; he says that terrestrial predators, especially small mammals and crepuscular/eocrepuscular bird predators are important selective agents. Time and energy consumed daily in locating an appropriate site for roosting, egg shortfall (an important factor influencing population dynamics in pierids and other butterflies which lay eggs singly Duffey, 1968; Courtney \& Duggan, 1983), and harm due to inclement weather were minimized with the acquisition of the roosting habit. Young (1971) explained gregarious night roosting in Morpho amathonte as a "by-product of the gregarious feeding" in the adults rather than a form of collective defence against predators. He found that feeding sites were located very near roosting sites and both were used on a day-to-day basis. The result may be an economy of energy (selecting feeding and roosting sites) to be channeled into reproductive activities.

If energy saving is paramount for the evolution of gregarious roosting, we should expect to find gregarious roosters in migratory or high dispersing species, both long and short-lived, which is indeed the case: long-lived, Danaus spp., E. elathea, Marpesia merops, and M. chiron (roosting and migratory habits for the latter two in DeVries, 1987; their long life was inferred from the five-month lifespan of M. berania in Benson \& Emmel, 1973). Examples of short-lived ones are Ascia monuste (Brown, 1992), Colias spp., and Phoebis spp. We should expect this also in very active, fast, or strong flyers (Heliconius spp., Dryas iulia, Dryadula phaetusa (Brown, 1992), Eueides lybia (DeVries, 1987), Marpesia berania, Morpho achilles (Brown, 1992), Morpho amathonte (Young, 1971), and Heliopetes arsalte (Brown, 1992). It is also predictable that gregarious roosting would not evolve in highly sedentary or crepuscular species (Methona themisto, Hamadryas spp., Calligo spp., Opsiphanes 
spp., Brassolis spp., Taygetis spp., Eryphanis spp.). Unpalatability, restricted home-ranges, and long adult life may not be fundamental traits characterizing gregarious roosting, while dispersal potential, duration of daily flight activity, and single egg laying or small clutch size (both imply several ovipositional events and the associated energetic cost) may be more important. Protocooperational energy saving may be a useful working hypothesis for the unsolved question of why heliconiines roost and specially why some species roost in some regions but not in others.

Acknowledgments - We are greatly indebted to Prof. Arthur M. Shapiro for his critical comments on the manuscript. Cecília Lomônaco de Paula kindly helped in field work in May 1993. Gilson R.P. Moreira made helpful comments on an earlier version of the paper. Thanks are also due to Núbia S. L. de Souza for drawing Figure 1.

\section{REFERENCES}

AE, S. A., 1957, Effects of photoperiod on Colias eurytheme. Lepid. News, 11: 207-214.

BENSON, W. W., 1972, Natural selection for Müllerian mimicry in Heliconius erato in Costa Rica. Science, 176: 936-939.

BENSON, W. W. \& EMMEL, P., 1973, Demography of gregariouly roosting populations of the nymphalid butterfly Marpesia berania in Costa Rica. Ecology, 54: 326-335.

BIEZANKO, C. M., 1958, Pieridae da zona Sueste do Rio Grande do Sul. Arch. Ent. Pelotas, pp. 2-15.

BRAKEFIELD, P. M. \& LARSEN, T. B., 1984, The evolutionary significance of dry and wet season forms in some tropical butterflies. Biol. J. Linn. Soc., 22: 1-12.

BRAKEFIELD, P. M., 1996, Seasonal polyphenism in butterflies and natural selection. Trends Ecol. Evol., 11: 275-277.

BROWN, K. S. Jr., 1992, Borboletas da Serra do Japi: diversidade, habitats, recursos alimentares e variação temporal. In: L. P. C. Morellato (ed.), História natural da serra do Japi: ecologia e preservação de uma área florestal no sudeste do Brasil. Campinas, Editora da UNICAMP/FAPESP, pp. 142-186.

CALVERT, W. H., HEDRICK, L. E. \& BROWER, L. P., 1979, Mortality of the Monarch Butterfly (Danaus plexippus L.): avian predation at five overwintering sites in Mexico. Science, 204: 847-851.

COURTNEY, S. P. \& DUGGAN, A. E., 1983, The population biology of the orange tip butterfly Anthocharis cardamines in Britain. Ecol. Entomol., 8: 271-281.

DeVRIES, P. J., 1987, The butterflies of Costa Rica and their natural history: Papilionidae, Pieridae, Nymphalidae. Princeton Univ. Press, 327p.

DOUGLAS, M. M. \& GRULA, J. W., 1978, Thermoregulatory adaptations allowing ecological range expansion by the pierid butterfly Nathalis iole Boisduval. Evolution, 32: 776-783.
DUFFEY, E., 1968, Ecological studies on the Large Copper butterfly Lycaena dispar Haw. batavus Obth at Woodwalton Fen NNR, Huntingdonshire. J. Appl. Ecol., 5: 69-96.

EBERT, H., 1969, On the frequency of butterflies in eastern Brazil, with a list of the butterfly fauna of Poços de Caldas, Minas Gerais. J. Lepid. Soc., 23(suppl. 3).

EHRLICH, P. R. \& GILBERT, L. E., 1973, Population structure and dynamics of the tropical butterfly Heliconius ethilla. Biotropica, 5: 69-82.

FORD, E. B., 1937, Problems of heredity in the Lepidoptera Biol. Rev., 12: 461-503.

FORD, E. B., 1940, Genetic research in the Lepidoptera. Ann. Eugen., 10: 227-252.

FORTUNATO, L. \& RUSZCZYK, A., 1997, Comunidades de lepidópteros frugívoros em áreas verdes urbanas e extraurbanas de Uberlândia, MG. Rev. Bras. Biol., 57: 79-87.

HAYES, J. L., 1981, The population ecology of a natural population of the pierid butterfly Colias alexandra. Oecologia, 49: 188-200.

HOVANITZ, W., 1941, Parallel ecogenotypical color variation in butterflies. Ecology, 22: 259-284.

JONES, R. E., 1992, Phenotypic variation in Australian Eurema species. Aust. J. Zool., 40: 371-383.

JONES, R. E., RIENKS, J. \& WILSON, L., 1985, Seasonally and environmentally induced polyphenism in Eurema laeta lineata (Lepidoptera: Pieridae). J. Aust. Entomol. Soc., 24: 161-167.

JONES, R. E. \& RIENKS, J., 1987, Reproductive seasonality in the Tropical genus Eurema (Lepidoptera: Pieridae). Biotropica, 19: 7-16.

KINGSOLVER, J. G., 1987, Evolution and coadaptation of thermoregulatory behavior and wing pigmentation pattern in pierid butterflies. Evolution, 41: 472-490.

KINGSOLVER, J. G., 1995a, Viability selection on seasonally polyphenic traits: wing melanin pattern in Western White Butterflies. Evolution, 49: 932-941.

KINGSOLVER, J. G., 1995b, Fitness consequences of seasonal polyphenism in Western White Butterflies. Evolution, 49: 942-954.

KINGSOLVER, J. G., 1996, Experimental manipulation of wing pigment pattern and survival in Western White butterflies. Am. Nat., 147: 298-306.

KINGSOLVER, J. G. \& WATT, W. B., 1983, Thermoregulatory strategies in Colias butterflies: thermal stress and the limits to adaptation in temporally varying environments. Am. Nat., 121: $32-35$.

KINGSOLVER, J. G. \& WIERNASZ, D. C., 1991, Seasonal polyphenism in wing-melanin pattern and thermoregulatory adaptation in Pieris butterflies. Am. Nat., 137: 816-830.

LEDERHOUSE, R. C., CODELlA, S. G. \& COWELL, P. J., 1987, Diurnal predation on roosting butterflies during inclement weather: a substantial source of mortality in the black swallowtail, Papilio polyxenes (Lepidoptera: Papilionidae). J. N. Y. Entomol. Soc., 95: 310-319. 
McLEOD, L., 1968, Controlled environment experiments with Precis octavia Cram. (Nymphalidae). J. Res. Lepid., 7: 1-18.

McLEOD, L., 1984, Seasonal polyphenism in African Precis butterflies. In: R. I. Vane-Wright \& P. R. Ackery (eds.), The biology of butterflies. Academic Press, London, pp. 313-315.

MUYSHONDT, A. \& MUYSHONDT, A., Jr., 1974, Gregarious seasonal roosting of Smyrna karwinskii adults (Nymphalidae) in El Salvador. J. Lepid. Soc., 28: 224-227.

NIELSEN, E. T., 1961, On the habits of the migratory butterfly Ascia monuste L. Biol. Medd., 23: 1-81.

NYLIN, S., 1989, Effects of changing photoperiods in the life cycle regulation of the comma butterfly, Polygonia c-album (Nymphalidae). Ecol. Entomol., 14: 209-218.

OWEN, D. F., 1971, Adaptation to man-made environments and phenology in Precis butterflies. Revue Zool. Bot. Afr., 83: $361-373$

OWEN, D. F., 1977, Species diversity and seasonal abundance in Charaxes butterflies (Nymphalidae) in a garden in Northern Nigeria. Bull PIFAN, 39: 346-350.

PARSONS, P. A., 1982, Adaptive strategies of colonizing animal species. Biol. Rev., 57: 117-148.

PIANKA, E. R., 1994, Evolutionary ecology. Harper Collins, New York.

RODRIGUES, J. J. S., BROWN, K. S., Jr. \& RUSZCZYK, A., 1993, Resources and conservation of Neotropical butterflies in urban forest fragments. Biol. Conserv., 64: 3-9.

ROITBERG, B. D. \& MANGEL, M., 1997, Individuals and landscape: behavior can mitigate landscape differences among habitats. Oikos, 80: 234-240.

ROMANOWSKY, H. P., GUS, R. \& ARAÚJO, A. M., 1985, Studies on the genetics and ecology of Heliconius erato (Lepid., Nymph.). III. Population size, preadult mortality, adult resources and polymorphism in natural populations. Rev. Bras. Biol., 45: 563-569.

RUTOWSKI, R., 1978, The form and function of ascending flights in Colias butterflies. Behav. Ecol. Sociobiol., 31 163-172.

SAALFELD, K. \& ARAÚJO, A. M., 1981, Studies on the genetics and ecology of Heliconius erato (Lepidoptera Nymphalidae). I. Demography of a natural population. Rev. Bras. Biol., 41: 855-860.

SCOTT, J. A., 1973, The lifespan of butterflies. J. Res. Lepid., 12: $225-230$.

SHAPIRO, A. M., 1974, Beak-mark frequency as an index of seasonal predation intensity on common butterflies. $\mathrm{Am}$. Nat., 108: 229-232.
SHAPIRO, A. M., 1976, Seasonal polyphenism. Evol. Biol., 9: 259-333.

SHAPIRO, A. M., 1984a, Polyphenism, phyletic evolution, and the structure of the pierid genome. J. Res. Lepid., 23: 177195.

SHAPIRO, A. M., 1984b, Experimental studies on the evolution of seasonal polyphenism. In: R. I. Vane-Wright \& P. R. Ackery (eds.), The biology of butterflies. Academic Press, London, pp. 297-311.

SHREEVE, T. G., 1981, Flight patterns of butterfly species in woodlands. Oecologia, 51:289-293.

SOUTHWOOD, T. R. E., 1962, Migration of terrestrial arthropods in relation to habitat. Biol. Rev., 37: 171-214.

SMITH, K. C., 1991, The effects of temperature and daylength on the rosa polyphenism in the buckeye butterfly, Precis coenia (Lepidoptera: Nymphalidae). J. Res. Lepid., 30: 237-244.

TURNER, J. R. G., 1975, Communal roosting in relation to warning colour in two heliconiine butterflies (Nymphalidae). J. Lepid. Soc., 29: 221-226.

VANINI, F., BONATO, V. \& FREITAS, A. V. L., 2000, Polyphenism and population biology of Eurema elathea (Lepidoptera: Pieridae) in a disturbed environment in Tropical Brazil. J. Lepid. Soc., 53: 159-168.

WALTER, H., 1971, Ecology of tropical and subtropical vegetation. Oliver and Boid, Edinburgh.

WATT, W. B., 1968, Adaptive significance of pigment polymorphisms in Colias butterflies. I Variation of melanin pigment in relation to thermoregulation. Evolution, 22: 437-458.

WEISMANN, A., 1882, Studies in the theory of descent. Trans. R. Meldola, Sampson, Low, London.

WEST-EBERHARD, M. J., 1989, Phenotypic plasticity and the origins of diversity. Ann. Rev. Ecol. Syst., 20: 249-278.

WINDIG, J. J., BRAKEFIELD, P. M., REITSMA, N. \& WILSON, J. G. M., 1994, Seasonal polyphenism in the wild: survey of wing patterns in five species of Byciclus butterflies in Malawi. Ecol. Entomol., 19: 285-298.

WINDIG, J. J. \& LAMMAR, P., 1999, Evolutionary genetics of seasonal polyphenism in the map butterfly. Evol. Ecol. Res., 1: 875-894.

WITH, K. A., GARDNER, R. H. \& TURNER, M. G., 1997, Landscape connectivity and population distribution in heterogeneous environments. Oikos, 78: 151-169.

YOUNG, A. M., 1971, Notes on gregarious roosting in tropical butterflies of the genus Morpho. J. Lepid. Soc., 25: 223-234.

YOUNG, A. M., 1972, Community ecology of some tropical rain forest butterflies. Am. Midl. Nat., 87: 146-157. 